\title{
The Effect of Nitric Oxide Combined with Fluoroquinolones against Salmonella enterica Serovar Typhimurium in Vitro

\author{
AY Coban ${ }^{+}$, B Durupinar
}

Department of Microbiology and Clinical Microbiology, Medical School, Ondokuz Mayis University, 55139, Samsun, Turkey

Two regulons, soxRS and marRAB, are associated with resistance to quinolones or multiple antibiotic in Salmonella enterica serovar Typhimurium. These regulons are activated by nitric oxide and redox-cycling drugs, such as paraquat and cause on activation of the acrAB-encoded efflux pump. In this study, we investigated the effect of nitric oxide (NO) alone and in combination with ofloxacin, ciprofloxacin, and pefloxacin against $\mathrm{S}$. typhimurium clinical isolates and mutant strains in vitro. We did not observe synergistic effect against clinical isolates and SH5014 (parent strain of acr mutant), while we found synergistic effect against PP120 (soxRS mutant) and SH7616 (an acr mutant) S. typhimurium for all quinolones. Our results suggest that the efficiencies of some antibiotics, including ofloxacin, ciprofloxacin, and pefloxacin are decreased via activation of soxRS and marRAB regulons by NO in $\mathrm{S}$. enterica serovar Typhimurium. Further studies are warranted to establish the interaction of NO with the genes of Salmonella and, with multiple antibiotic resistance.

Key words: nitric oxide - Salmonella enterica serovar Typhimurium - diazeniumdiolate

It has been shown before that endothelial (eNOS), neuronal and inducible (iNOS) types of nitric oxide (NO) synthases are involved in the production of NO in healthy humans and contribute to the intracellular killing of intracellular pathogens like Salmonella, Legionella pneumophila, Mycobacterium tuberculosis and Leishmania (Long et al. 1999). These pathogens include in their infection pathogenesis a phase during which they grow within macrophages (Eriksson et al. 2000). High-output pathways for production of reactive oxygen intermediates via the respiratory burst and reactive nitrogen intermediates via iNOS are presently the major molecularly defined means by which activated macrophages are thought to inhibit facultative or obligate intracellular pathogens (Shiloh \& Nathan 2000). The cytotoxicity promoted by NO mainly depends on the interaction of $\mathrm{NO}$ with iron-containing moieties of the key enzymes of DNA replication and respiratory cycle in the target cells (Moncado \& Higgs 1993). As NO has other important functions in metabolic processes in humans, the possible occurence of an unaccetaple side effect is a major drawback in the usage of NO for antimicrobial chemotherapy. Instability, limited solubility and the absence of a reliable delivery method complicates further the consideration of $\mathrm{NO}$ as an antimicrobial agent. NO-nucleophile complexes termed diazeniumdiolates are compounds with such specifications like the capability of releasing $\mathrm{NO}$ in aqueous or low $\mathrm{pH}$ environments without the need of a redox reaction or electron transfer and might be useful to overcome those barriers to develop an effective antimicrobial chemotherapy based on NO (McElhaney-Feser et al. 1998) .

\footnotetext{
${ }^{+}$Corresponding author. Fax: +90-362-457.6041. E-mail: noahmet@yahoo.com

Received 13 September 2002

Accepted 5 December 2002
}

Since S. typhimurium is an intracellular pathogen, antibiotics are to be effective needed to achieve high intracellular concentrations. Fluoroquinolones, including ofloxacin, ciprofloxacin, pefloxacin, and sparfloxacin have been shown to achieve high intracellular concentrations (Schüler et al. 1997).

In this study, initially, we investigated the effect of NO against $S$. typhimurium and further interaction with ofloxacin, ciprofloxacin, and pefloxacin between $\mathrm{NO}$ was evaluated against clinical isolates and mutant strains in vitro.

\section{MATERIALS AND METHODS}

Bacterial strains - Table I shows the bacteria used in this study.

Antibacterial agents - NO donor DETA-NO $\{(\mathrm{Z})-1$ [N-(2-aminoethyl)-N-(2-ammonioethyl)amino]diazen-1ium-1,2-diolate\} was kindly gifted by Joseph A Hrabie and Larry Keefer, National Cancer Institute, Frederick Cancer Research Center, Frederick, Md. Ofloxacin, ciprofloxacin, pefloxacin were obtained "Hoechst Marion Roussel”, "Bayer Turk Kimya San. Ltd. Sti.", "Eczacibasi Rhone Poulenc", respectively. DETA-NO was dissolved in $0.1 \mathrm{~N} \mathrm{NaOH}$ and antibiotics were dissolved by manufacture's instructions.

Broth microdilution assay and growth media - Minimum inhibitory concentrations (MICs) were determined by the broth microdilution method in cation-adjusted Mueller-Hinton broth according to the standards of the National Committee for Clinical Laboratory Standards (NCCLS 1997). DETA-NO was tested at concentrations 8$0.06 \mathrm{mg} / \mathrm{ml}$ for all clinical isolates and PP120, SH5014 and SH7616. Ofloxacin, ciprofloxacin, pefloxacin were tested at concentrations $4-0.003 \mu \mathrm{g} / \mathrm{ml}$ for all clinical isolates, and at concentrations $0.5-0.0003 \mu \mathrm{g} / \mathrm{ml}$ for PP120, SH5014 and SH7616. The MIC was the lowest concentration of antibiotic that yielded no visible growth after incubation at $37^{\circ} \mathrm{C}$ for $24-48 \mathrm{~h}$. 
TABLE I

Characteristics of strains used in this study

\begin{tabular}{lll}
\hline Strains & Relevant properties & Source or reference \\
\hline Salmonella typhimurium & 15 clinical isolates & $\begin{array}{l}\text { Birsel Erdem (Ankara University, Medical School, Department } \\
\text { of Microbiology, Turkey) } \\
\text { Bruce Demple (Department of Cancer Cell Biology, Harvard School } \\
\text { of Public Health, Boston, MA, USA) }\end{array}$ \\
SH7616 & $\begin{array}{l}\text { AsoxRS } \\
\text { an } \text { acr mutant }\end{array}$ & $\begin{array}{l}\text { Hiroshi Nikaido (Department of Molecular and Cell Biology, } \\
\text { University of California, Berkeley, CA, USA) }\end{array}$ \\
pH5014 & parent strain of acr mutant & $\begin{array}{l}\text { Hiroshi Nikaido (Department of Molecular and Cell Biology, } \\
\text { University of California, Berkeley, CA, USA) }\end{array}$ \\
\hline
\end{tabular}

Broth microdilution combination assay - Checkerboard testing was performed by the microdilution method in microtiter trays with cation-adjusted Mueller-Hinton broth as described (White et al. 1996, Climo et al. 1999). Combinations of DETA-NO with ofloxacin, ciprofloxacin, pefloxacin were tested at concentrations $4-0.06 \mathrm{mg} / \mathrm{ml}$ with 4- $0.003 \mu \mathrm{g} / \mathrm{ml}$ for all clinical isolates and were tested at 4$0.06 \mathrm{mg} / \mathrm{ml}$ with $0.5-0.0003 \mu \mathrm{g} / \mathrm{ml}$ for PP120, SH5014 and $\mathrm{SH7616}$, respectively. Microtiter plates were incubated at $37^{\circ} \mathrm{C}$ and were read at 24 and $48 \mathrm{~h}$. All tests were performed two times. The fractional inhibitory concentration (FIC) index was calculated by adding the FICs (MIC of drug $\mathrm{A}$ in combination with drug $\mathrm{B} / \mathrm{MIC}$ of drug A alone) of DETA-NO and antibiotics. An FIC index of $\leq 0.5$ defined as synergy, an FIC index of $>0.5$ to $\leq 4.0$ was defined as additive or indifference, and an FIC index of $>4.0$ was defined as antagonistic (White et al. 1996, Climo et al. 1999).

The control of $\mathrm{NO}$ releasing from DETA-NO - NO releasing was confirmed by Greiss reagent ( $1 \%$ sulfanilamide, $0.1 \%$ naphthylethylene diamine dihydrochloride, $2.5 \%$
$\mathrm{H}_{3} \mathrm{PO}_{4}$ ) (Igietseme et al. 1998). NO releasing was confirmed by occur light to dark purple.

\section{RESULTS}

In this study, all clinical isolates were found to be susceptible to ofloxacin, ciprofloxacin, pefloxacin. The MIC values for DETA-NO were $1-2 \mathrm{mg} / \mathrm{ml}$ in S. typhimurium (Table II-IV). In the combination test, no synergistic effect was observed between DETA-NO and antibiotics against $S$. typhimurium isolates. In $S$. typhimurium isolates, antagonistic effect was noted in one isolate for ofloxacin (isolate 13), 9 isolates for pefloxacin (isolates 4, $6,7,9,10,11,13,14$, and 15). There was no antagonistic effect for ciprofloxacin (Table II-IV). However, we observed synergistic effect, except with SH5014 (parent strain), of DETA-NO with ofloxacin, ciprofloxacin, pefloxacin against PP120 (soxRS) and SH7616 (an acr mutant) (Table V).

Overall ofloxacin, ciprofloxacin, pefloxacin alone were effective against $S$. typhimurium, but combinations of DETA-NO with these agents were interestingly less effective against some isolates than alone.

\section{TABLE II}

Checkerboard assay of the effect of DETA-NO \{(Z)-1-[N-(2-aminoethyl)-N-(2-ammonioethyl)amino]diazen-1-ium-1,2-diolate $\}$ and ofloxacin alone and in combination against Salmonella enterica serovar Typhimurium isolates

\begin{tabular}{|c|c|c|c|c|c|c|}
\hline \multirow[b]{2}{*}{ Strains } & \multicolumn{2}{|c|}{ MIC DETA-NO } & \multicolumn{2}{|c|}{ MIC Ofloxacin } & \multirow[b]{2}{*}{ FIX index } & \multirow[b]{2}{*}{ Outcome } \\
\hline & $\begin{array}{l}\text { Alone } \\
(\mathrm{mg} / \mathrm{ml})\end{array}$ & $\begin{array}{l}\text { With ofx } \\
(\mathrm{mg} / \mathrm{ml})\end{array}$ & $\begin{array}{l}\text { Alone } \\
(\mu \mathrm{g} / \mathrm{ml})\end{array}$ & $\begin{array}{c}\text { With DETA-NO } \\
(\mu \mathrm{g} / \mathrm{ml})\end{array}$ & & \\
\hline KUEN & 1 & 0.5 & 0.06 & 0.06 & 1.5 & Add or ind \\
\hline 1 & 1 & 0.5 & 0.06 & 0.06 & 1.5 & Add or ind \\
\hline 2 & 2 & 0.5 & 0.125 & 0.125 & 1.25 & Add or ind \\
\hline 3 & 2 & 0.5 & 0.06 & 0.125 & 2.33 & Add or ind \\
\hline 4 & 2 & 1 & 0.06 & 0.125 & 2.58 & Add or ind \\
\hline 5 & 2 & 1 & 0.06 & 0.125 & 2.58 & Add or ind \\
\hline 6 & 2 & 0.5 & 0.06 & 0.06 & 1.25 & Add or ind \\
\hline 7 & 2 & 0.5 & 0.03 & 0.06 & 2.25 & Add or ind \\
\hline 8 & 2 & 0.5 & 0.06 & 0.06 & 1.25 & Add or ind \\
\hline 9 & 2 & 0.5 & 0.06 & 0.06 & 1.25 & Add or ind \\
\hline 10 & 2 & 0.5 & 0.06 & 0.06 & 1.25 & Add or ind \\
\hline 11 & 2 & 0.5 & 0.06 & 0.06 & 1.25 & Add or ind \\
\hline 12 & 2 & 0.5 & 0.06 & 0.06 & 1.25 & Add or ind \\
\hline 13 & 2 & 1 & 0.03 & 0.125 & 4.6 & Antagonist \\
\hline 14 & 2 & 0.5 & 0.06 & 0.06 & 1.25 & Add or ind \\
\hline 15 & 2 & 0.25 & 0.06 & 0.03 & 0.625 & Add or ind \\
\hline
\end{tabular}

ofx: ofloxacin; add or ind: additive or indifference 
TABLE III

Checkerboard assay of the effect of DETA-NO NO \{(Z)-1-[N-(2-aminoethyl)-N-(2-ammonioethyl)amino]diazen-1-ium-1,2diolate $\}$ and ciprofloxacin alone and in combination against Samonella typhimurium isolates

\begin{tabular}{|c|c|c|c|c|c|c|}
\hline \multirow[b]{2}{*}{ Strains } & \multicolumn{2}{|c|}{ MIC DETA-NO } & \multicolumn{2}{|c|}{ MIC Ciprofloxacin } & \multirow[b]{2}{*}{ FIX index } & \multirow[b]{2}{*}{ Outcome } \\
\hline & $\begin{array}{l}\text { Alone } \\
(\mathrm{mg} / \mathrm{ml})\end{array}$ & $\begin{array}{l}\text { With cip } \\
(\mathrm{mg} / \mathrm{ml})\end{array}$ & $\begin{array}{l}\text { Alone } \\
(\mu \mathrm{g} / \mathrm{ml})\end{array}$ & $\begin{array}{l}\text { With DETA-NO } \\
(\mu \mathrm{g} / \mathrm{ml})\end{array}$ & & \\
\hline KUEN & 1 & 0.125 & 0.03 & 0.015 & 0.625 & Add or ind \\
\hline 1 & 1 & 0.25 & 0.007 & 0.007 & 1.25 & Add or ind \\
\hline 2 & 2 & 0.25 & 0.007 & 0.007 & 1.125 & Add or ind \\
\hline 3 & 2 & 0.25 & 0.015 & 0.007 & 0.59 & Add or ind \\
\hline 4 & 2 & 0.25 & 0.007 & 0.007 & 1.125 & Add or ind \\
\hline 5 & 2 & 0.25 & 0.007 & 0.015 & 2.26 & Add or ind \\
\hline 6 & 2 & 0.5 & 0.007 & 0.015 & 2.39 & Add or ind \\
\hline 7 & 2 & 0.25 & 0.007 & 0.015 & 2.26 & Add or ind \\
\hline 8 & 2 & 0.25 & 0.007 & 0.007 & 1.125 & Add or ind \\
\hline 9 & 2 & 0.25 & 0.007 & 0.007 & 1.125 & Add or ind \\
\hline 10 & 2 & 0.25 & 0.015 & 0.007 & 0.59 & Add or ind \\
\hline 11 & 2 & 0.25 & 0.007 & 0.007 & 1.125 & Add or ind \\
\hline 12 & 2 & 0.25 & 0.007 & 0.007 & 1.125 & Add or ind \\
\hline 13 & 2 & 0.25 & 0.007 & 0.007 & 1.125 & Add or ind \\
\hline 14 & 2 & 0.25 & 0.015 & 0.007 & 0.59 & Add or ind \\
\hline 15 & 2 & 0.5 & 0.015 & 0.007 & 0.76 & Add or ind \\
\hline
\end{tabular}

cip: ciprofloxacin; add or ind: additive or indifference

TABLE IV

Checkerboard assay of the effect of DETA-NO \{(Z)-1-[N-(2-aminoethyl)-N-(2-ammonioethyl)amino]diazen-1-ium-1,2-diolate $\}$ and pefloxacin alone and in combination against Salmonella typhimurium isolates

\begin{tabular}{|c|c|c|c|c|c|c|}
\hline \multirow[b]{2}{*}{ Strains } & \multicolumn{2}{|c|}{ MIC DETA-NO } & \multicolumn{2}{|c|}{ MIC Pefloxacin } & \multirow[b]{2}{*}{ FIX index } & \multirow[b]{2}{*}{ Outcome } \\
\hline & $\begin{array}{l}\text { Alone } \\
(\mathrm{mg} / \mathrm{ml})\end{array}$ & $\begin{array}{l}\text { With pef } \\
(\mathrm{mg} / \mathrm{ml})\end{array}$ & $\begin{array}{l}\text { Alone } \\
(\mu \mathrm{g} / \mathrm{ml})\end{array}$ & $\begin{array}{l}\text { With DETA-NO } \\
\qquad(\mu \mathrm{g} / \mathrm{ml})\end{array}$ & & \\
\hline KUEN & 1 & 0.25 & 0.125 & 0.125 & 1.25 & Add or ind \\
\hline 1 & 1 & 0.5 & 0.125 & 0.06 & 0.98 & Add or ind \\
\hline 2 & 2 & 1 & 0.125 & 0.125 & 1.5 & Add or ind \\
\hline 3 & 2 & 1 & 0.125 & 0.125 & 1.5 & Add or ind \\
\hline 4 & 2 & 1 & 0.06 & 0.25 & 4.6 & Antagonist \\
\hline 5 & 2 & 1 & 0.125 & 0.25 & 2.5 & Add or ind \\
\hline 6 & 2 & 1 & 0.06 & 0.25 & 4.6 & Antagonist \\
\hline 7 & 2 & 1 & 0.06 & 0.25 & 4.6 & Antagonist \\
\hline 8 & 2 & 1 & 0.125 & 0.25 & 2.5 & Add or ind \\
\hline 9 & 2 & 1 & 0.06 & 0.25 & 4.6 & Antagonist \\
\hline 10 & 2 & 1 & 0.06 & 0.25 & 4.6 & Antagonist \\
\hline 11 & 2 & 1 & 0.06 & 0.25 & 4.6 & Antagonist \\
\hline 12 & 2 & 1 & 0.125 & 0.125 & 1.5 & Add or ind \\
\hline 13 & 2 & 1 & 0.06 & 0.25 & 4.6 & Antagonist \\
\hline 14 & 2 & 1 & 0.06 & 0.25 & 4.6 & Antagonist \\
\hline 15 & 2 & 1 & 0.06 & 0.25 & 4.6 & Antagonist \\
\hline
\end{tabular}

pef: pefloxacin; add or ind: additive or indifference

\section{DISCUSSION}

The antimicrobial activity of NO is well known but the therapeutic value of $\mathrm{NO}$ as a antimicrobial agent is not clear (McElhaney-Feser et al. 1998). In addition, no sufficient data is available about the interaction NO and antibiotics in vivo. Our study suggested that the combinations of DETA-NO with ofloxacin, ciprofloxacin, and pefloxacin provided no synergistic effect against $S$. typhimurium clinical isolates and SH5014 in vitro. However, synergistic effect against PP120, SH7616 was ob- served when DETA-NO was combined with ofloxacin, ciprofloxacin and pefloxacin (Table II-V).

Two regulons, $\operatorname{mar} R A B$ and $\operatorname{sox} R S$, are reported to play role in the chromosomal based resistance for multiple antibiotics in S. typhimurium and Escherichia coli. Oxidation or nitrosylation of SoxR triggers transcription of the Sox $S$ response genes in the sox $R S$ system (Koutsolioutsou et al. 2001). SoxS protein, which is a member of the AraC/ $X y l S$ family of transcriptional regulators, activates at least 15 genes including $\operatorname{sod} A$ (Mn-containing superoxide 
TABLE V

Checkerboard assay of the effect of DETA-NO \{(Z)-1-[N-(2-aminoethyl)-N-(2-ammonioethyl)amino]diazen-1-ium-1,2-diolate $\}$ and ofloxacin, ciprofloxacin, pefloxacin alone and in combination against PP120 (soxRS mutant), SH7616 (an acr mutant), SH5014 (parent strain)

\begin{tabular}{|c|c|c|c|c|c|c|}
\hline & $\begin{array}{l}\text { MIC DETA-NO } \\
\text { Alone }(\mathrm{mg} / \mathrm{ml})\end{array}$ & $\begin{array}{c}\text { MIC ofx } \\
\text { Alone }(\mu \mathrm{g} / \mathrm{ml})\end{array}$ & $\begin{array}{c}\text { MIC DETA-NO } \\
\text { Comb with ofx }(\mathrm{mg} / \mathrm{ml})\end{array}$ & $\begin{array}{c}\text { MIC ofx Comb } \\
\text { with DETA-NO }(\mu \mathrm{g} / \mathrm{ml})\end{array}$ & FIX index & Outcome \\
\hline PP120 & 2 & 0.25 & 0.25 & 0.06 & 0.365 & Synergy \\
\hline SH7616 & 1 & 0.125 & 0.25 & 0.015 & 0.370 & Synergy \\
\hline \multirow[t]{2}{*}{ SH5014 } & 2 & 0.25 & 0.5 & 0.125 & 0.750 & Add or ind \\
\hline & $\begin{array}{l}\text { MIC DETA-NO } \\
\text { Alone }(\mathrm{mg} / \mathrm{ml})\end{array}$ & $\begin{array}{c}\text { MIC cip } \\
\text { Alone }(\mu \mathrm{g} / \mathrm{ml})\end{array}$ & $\begin{array}{c}\text { MIC DETA-NO } \\
\text { Comb with cip }(\mathrm{mg} / \mathrm{ml})\end{array}$ & $\begin{array}{c}\text { MIC cip Comb } \\
\text { with DETA-NO }(\mu \mathrm{g} / \mathrm{ml})\end{array}$ & FIX index & Outcome \\
\hline $\begin{array}{l}\text { PP120 } \\
\text { SH7616 } \\
\text { SH5014 }\end{array}$ & $\begin{array}{l}2 \\
1 \\
2\end{array}$ & $\begin{array}{l}0.06 \\
0.06 \\
0.03\end{array}$ & $\begin{array}{l}0.125 \\
0.25 \\
0.5\end{array}$ & $\begin{array}{l}0.015 \\
0.007 \\
0.015\end{array}$ & $\begin{array}{l}\mathbf{0 . 3 1 2} \\
\mathbf{0 . 3 6 6} \\
0.750\end{array}$ & $\begin{array}{r}\text { Synergy } \\
\text { Synergy } \\
\text { Add or ind }\end{array}$ \\
\hline SH5014 & $\begin{array}{l}\text { MIC DETA-NO } \\
\text { Alone }(\mathrm{mg} / \mathrm{ml})\end{array}$ & $\begin{array}{c}\text { MIC pef } \\
\text { Alone }(\mu \mathrm{g} / \mathrm{ml}) \\
\end{array}$ & $\begin{array}{c}\text { MIC DETA-NO } \\
\text { Comb with pef }(\mathrm{mg} / \mathrm{ml})\end{array}$ & $\begin{array}{c}\text { MIC pef Comb } \\
\text { with DETA-NO }(\mu \mathrm{g} / \mathrm{ml})\end{array}$ & FIX & Outcome \\
\hline $\begin{array}{l}\text { PP120 } \\
\text { SH7616 } \\
\text { SH5014 }\end{array}$ & $\begin{array}{l}2 \\
1 \\
2\end{array}$ & $\begin{array}{l}0.25 \\
0.25 \\
0.25\end{array}$ & $\begin{array}{l}0.25 \\
0.125 \\
1\end{array}$ & $\begin{array}{l}0.06 \\
0.007 \\
0.06\end{array}$ & $\begin{array}{l}\mathbf{0 . 3 6 5} \\
\mathbf{0 . 1 5 3} \\
0.740\end{array}$ & $\begin{array}{r}\text { Synergy } \\
\text { Synergy } \\
\text { Add or ind }\end{array}$ \\
\hline
\end{tabular}

Oxf: ofloxacin; cip: ciprofloxacin; pef: pefloxacin; add or ind: additive or indifference

dismutase), zwf (glucose-6-phosphate dehydrogenase), $m i c F$ (antisense RNA to the porin OmpF mRNA), nfo (DNA repair endonuclease IV), fpr (NADPH: ferrodoxin oxidoreductase), $\operatorname{acr} A B$ (efflux pump), acn $A$ (aconitase), fum $C$ (heat-resistant fumarase) and $n f_{S A}$ (nitroreductase A) (Pomposiello \& Demple 2000).

Antibiotic resistance mediated by both $\operatorname{sox} R S$ and $\operatorname{mar} R A B$ depends on activation of the $\operatorname{acr} A B$-encoded efflux pump and downregulation of the outer membrane porin OmpF which is mediated by the antisense RNA of micF gene (Koutsolioutsou et al. 2001).

Recently, it has been shown that the sox $R S$ regulon is activated by NO and redox-cycling drugs such as paraquat, and transient expression of $\operatorname{sox} R S$ or $\operatorname{mar} R A B$ regulates resistance functions in $S$. typhimurium (Koutsolioutsou et al. 2001). Koutsolioutsou et al. (2001) suggested that constitutively expressed sox $R$ render $S$. typhimurium resistant to quinolone and that antibiotic treatments cause a constitutive mutation in soxR. Ding and Demple (2000) monitored the effect of NO on the activity of soxR in E. coli by using reporter fusions to the SoxR promoter, and reported that infusion of pure NO gas activates $\operatorname{sox} R$. This activation was shown to be enhanced by the removal of oxygen, which indicates a direct reaction of $\mathrm{NO}$ with a cellular target in competition with $\mathrm{O}_{2}$.

In Salmonella, the multiple antibiotic resistance has not been elucidated well. Some resistant mutants have reduced expression of $\mathrm{OmpF}$, while others have had no porin changes. However, the $\operatorname{marR} A B$ loci and soxRS genes in $S$. typhimurium has been shown to be structurally and functionally similar to those in E. coli. Ciprofloxacin resistant $S$. typhimurium mutants have been shown to overexpress $A$ crA, which also suggest that the $A c r A B$ efflux pump is involved in multiple antibiotic resistance (Piddock et al. 2000). Nikaido et al. (1998) re- ported that SS-B drug-supersusceptible mutant of $S$. typhimurium had a mutation in the $\operatorname{acr} A B$ operon.

Given the above mentioned aspects, it has been thought that the induction of specific regulons (marR $A B$, SoxRS) and consequently the activation of acr $A B$ efflux pump might be the possible cause of additive or indifference and antagonistic effects observed between DETA$\mathrm{NO}$ and ofloxacin, ciprofloxacin and pefloxacin against the clinical isolates used in this study. To illuminate this point, soxRS (PP120) and acrAB (SH7616) mutant strains were used in the second step of the study, and 4-10 fold decreases in MIC values with DETA-NO and antibiotic combinations against mutant strains were achieved (Table V). In support of these findings, McElhaney-Feser et al. (1998) recently reported a synergistic effect of DETA-NO in combination with ketoconazole, fluconazole and miconazole against Candida species in vitro.

Our results suggest that an intracellular pathogen such as $S$. typhimurium is able to protect itself by activating the genes that results in antibiotic resistance when exposed to NO. This characteristic function may have an implication during clinical therapy as such that formation of efflux pump related resistance may be expected. For understanding the exact mechanism further studies are warranted to establish the interaction of $\mathrm{NO}$ with the genes of Salmonella and multiple antibiotic resistance.

\section{ACKNOWLEDGMENTS}

To Joseph A Hrabie and Larry Keefer for providing us with DETA-NO used in this study. To Bruce Demple, Hiroshi Nikaido and Birsel Erdem for providing PP120, SH5014, SH7616 and Salmonella enterica serovar Typhimurium clinical isolates.

\section{REFERENCES}

Climo MW, Patron RL, Archer GL 1999. Combinations of vancomycin and $\beta$-lactams are synergistic against staphylo- 
cocci with reduced susceptibilities to vancomycin. Antimicrob Agents Chemother 43: 1747-1753.

Ding H, Demple B 2000. Direct nitric oxide signal transduction via nitrosylation of iron-sulfur centers in the SoxR transcription activator. Proc Natl Acad Sci USA 97: 5146-5150.

Eriksson S, Björkman J, Borg S, Syk A, Pettersson S, Andersson DI, Rhen M 2000. Salmonella typhimurium mutants that downregulate phagocyte nitric oxide production. Cell Microbiol 2: 239-250.

Igietseme JU, Perry LL, Ananaba GA, Uriri IM, Ojior OO, Kumar SN, Caldwell HD 1998. Chlamydial infection in inducible nitric oxide synthase knockout mice. Infect Immun 66: 1282-1286.

Koutsolioutsou A, Martins EA, White DG, Levy SB, Demple B 2001. A soxRS-constitutive mutation contributing to antibiotic resistance in a clinical isolate of Salmonella enterica (Serovar Typhimurium). Antimicrob Agents Chemother 45: 38-43.

Long R, Light B, Talbot JA 1999. Mycobacteriocidal action of exogenous nitric oxide. Antimicrob Agents Chemother 43: 403-405.

McElhaney-Feser GE, Raulli RE, Cihlar RL 1998. Synergy of nitric oxide and azoles against Candida species in vitro. Antimicrob Agents Chemother 42: 2342-2346.

Moncado S, Higgs A 1993. The L-arginine-nitric oxide pathway. New Eng J Med 329: 2002-2010.

NCCLS-National Committee for Clinical Laboratory Standards
1997. Methods for Dilution Antimicrobial Susceptibility Test for Bacteria that Grow Aerobically. Approved standard M7A4, 4th ed., National Committee for Clinical Laboratory Standards, Wayne, $\mathrm{Pa}$.

Nikaido H, Basina M, Nguyen VY, Rosenberg EY 1998. Multidrug efflux pump AcrAB of Salmonella typhimurium excretes only those $\beta$-lactam antibiotics containing lipophilic side chains. J Bacteriol 180: 4686-4692.

Piddock LJV, White DG, Gensberg K, Pumbwe L, Griggs DJ 2000. Evidence for an efflux pump mediating multiple antibiotic resistance in Salmonella enterica serovar Typhimurium. Antimicrob Agents Chemother 44: 31183121.

Pomposiello PJ, Demple B 2000. Identification of SoxS-regulated genes in Salmonella enterica serovar Typhimurium. Antimicrob Agents Chemother 182: 23-29.

Schüler P, Zemper K, Borner K, Koeppe P, Schaberg T, Lode H 1997. Penetration of sparfloxacin and ciprofloxacin into alveolar macrophages, epithelial lining fluid, and polymorphoneclear leucocytes. Eur Respir J 10: 1130-1136.

Shiloh MU, Nathan CF 2000. Reactive nitrogen intermediates and the pathogenesis of Salmonella and mycobacteria. Cur Opin Microbiol 3: 35-42.

White RL, Burgess DS, Manduru M, Bosso JA 1996. Comparison of three different in vitro methods of detecting synergy: time-kill, checkerboard, and E test. Antimicrob Agents Chemother 40: 1914-1918. 